\title{
Pociągający widok przemocy?
}

\author{
Wywiad z Pierre'em Schoentjes'em przeprowadzony \\ w języku francuskim i przetłumaczony \\ na język polski przez Piotra Sadkowskiego ${ }^{\star}$
}

DOI: http://dx.doi.org/10.12775/LC.2018.038

Pierre Schoentjes jest romanistą, profesorem literatury na Uniwersytecie Gandawskim. Jego badania dotyczą tematyki wojennej, ironii, ekologii w literaturach współczesnych.

Redaktor: Istotna część Pana pracy badawczej poświęcona jest literackim przedstawieniom Wielkiej Wojny, w szczególności narracyjnym sposobom obrazowania okropieństw i przemocy. Jednak konflikt $\mathrm{z}$ lat 1914-1918 sytuuje się w pańskich projektach naukowych $\mathrm{w}$ sąsiedztwie tematów odnoszących się do innych wojen. Interesuje się Pan Profesor tematem ludobójstwa w literaturze, obecnością wojny algierskiej we współczesnej powieści francuskiej, narracjami o przemocy w byłej Jugosławii i w Rwandzie, weteranami wojen w Afganistanie i Iraku. Czy te rozmaite perspektywy pozwalają mówić o wyróżnikach I wojny sprawiających, że jej fikcjonalny obraz wymyka się porównaniom z literackimi reprezentacjami innych wojen? Czy wręcz przeciwnie, Wielka Wojna, w tym kontekście, jawilaby się jako jeden z przypadków uniwersalnego problemu, jakim jest wojna, jako jedna $\mathrm{z}$ wielu wojen $\mathrm{w}$ historii?

Pierre Schoentjes (dalej P. S.): Moje osobiste zainteresowanie wojną sięga czasów młodości. Jeden z moich dziadków, z wykształcenia inżynier, ale z zamiłowania literat, zachęciłmnie bardzo wcześnie dolektury powieści, które miały dla niego dużeznaczenie w okresie międzywojennym. Książki autorów, których już się nie czytało pod koniec lat siedemdziesiątych. Wśród nich byli Maurice Genevoix (lubiłem też jego książki o naturze), Georges Duhamel, Jules Romains, Roger Martin du Gard (trochę mniej zapomniany w owym czasie, o którym pięknie pisał Camus) i oczywiście Roland Dorgelès i Henri Barbusse. Dziadek jako oficer kawalerii poszedł na tzw. dziwną wojnę w 1939 roku z dwiema książkami filozofa Alaina ${ }^{1}$ w ekwipunku: Mars ou la guerre jugée (Mars albo wojna osadzona) i Souvenirs de guerre (Wspomnienia wojenne) ${ }^{2}$. Był pod wielkim wrażeniem tego

\footnotetext{
Dr hab., adiunkt w Katedrze Filologii Romańskiej Uniwersytetu Mikołaja Kopernika w Toruniu. Jego badania koncentrują się na współczesnych literaturach francuskojęzycznych. E-mail: piotr.sadkowski@umk.pl.

1 Alain - pseudonim Émile'a Chariera (1868-1951), francuskiego dziennikarza i filozofa.

2 Zob. Alain 1921. Mars ou la guerre jugée. Paris: Nouvelle Revue Française; idem 1937. Souvenirs de guerre. Paris: Paul Hartamann.
} 
myśliciela, który w 1914 roku miał już czterdzieści sześć lat, a więc mógłby być zwolniony z obowiązku wojskowego, a mimo to, w obliczu agresji na Francję, wyruszył na wojnę. Alain pozostał jednak głęboko przekonanym pacyfistą i odmawiał awansu na stanowisko dowódcze. Rzeczywistość okopów poznał jako zwykły żołnierz, a nie oficer. Ciągle mam egzemplarz Souvenirs de guerre, który towarzyszył mojemu dziadkowi podczas krótkiej, osiemnastodniowej kampanii. Kiedy byłem studentem pierwszego roku literatury, dałem tę książkę do oprawienia. Większość książek wymienionych tu przed chwilą autorów wyraża pewną formę humanizmu (paternalistycznego u Genevoix, mieszczańskiego u Duhamela), którą, niesłusznie, $\mathrm{w}$ tamtym czasie oceniałem jako przestarzałą. A dziadek przedstawiał mi te utwory, które naznaczyły jego własną młodość, jako środek, obok wspólnej Europy, mający pozwolić uniknąć wojen w przyszłości. Było to dosyć paradoksalne, kiedy pomyśli się, że cała literatura „pacyfistyczna” okresu międzywojennego nie była w stanie nic zrobić, by zapobiec rosnącej sile faszyzmu i istnieniu obozów. Ale jeśli kocha się literaturę, chce się wierzyć w jej moc. A potem inne lektury usunęły mi w cień świat Wielkiej Wojny. Były to dzieła klasyków, których wartość literacka jawiła się w sposób oczywisty, ale także powieści bardziej związane z ówczesnymi wydarzeniami. Dlatego o wiele później powróciłem do konfliktu z lat 1914-1918, pod wpływem prac historyków i kilku utworów literackich zwłaszcza powieści Pola chwały Jeana Rouauda, z roku $1990^{3}$, i komiksu C'était la guerre des tranchées (To była wojna w okopach) Jacques’a Tardiego ${ }^{4}$, które nadały nowej aktualności tej tematyce. Długo się wahałem nad wyborem problematyki badawczej, a pod wpływem ważnych lektur o Szoah, skłaniałem się do skupienia na tym zjawisku. Ale w końcu uznałem, że ten obszar w literaturze jest już w znacznej mierze zajęty i że okropieństwa jeszcze bardziej skrajnego niż w przypadku I wojny - z ważnych względów etycznych nie da się ująć w ramach dyskursu, w którym można byłoby skoncentrować się na formie badanych dzieł. Powrót do tematu Wielkiej Wojny dawał mi też możliwość zajęcia się światem konkretu, cielesnością, po okresie badań nad ironią, które doprowadziły mnie do eksplorowania gier językowych charakterystycznych dla postmodernizmu lat dziewięćdziesiątych $^{5}$. Ponadto pacyfizm jawił się mojemu pokoleniu jako coś oczywistego. Moją dysertację na zakończenie szkoły średniej poświęciłem wojnie w Wietnamie i, oczywiście, wszyscy byliśmy przeciw interwencji amerykańskiej. U progu lat osiemdziesiątych ta wojna była już, rzecz jasna, odległa, ale w rzeczywistości pozostawała bardzo obecna poprzez filmy, z Czasem Apokalipsy na pierwszym miejscu, które głęboko naznaczyły całe moje pokolenie. W perspektywie pacyfistycznej można było mieć zgodne stanowisko co do hekatomby z lat 1914-1918: konflikt uchodził za wojnę par excellence absurdalną, a żołnierzy uważano za ofiary. Taki obraz w znacznej mierze został wytworzony przez samych weteranów, którzy zgodnie z hasłem „nigdy więcej” wykazywali bardziej pragnienie eksponowania poniesionych cierpień niż popełnionych aktów przemocy. Oczywiście w efekcie industrializacji wojny takie postawy, jak osobiste bohaterstwo, świadome wystawienie się na niebezpieczeństwo, nie cieszyły się już taką estymą jak w czasie dawniejszych wojen. To, co mnie interesowało, to była analiza szerokiego zbioru tekstów, na który składały się utwory fikcjonalne, zarówno pacyfistyczne, jak i nacjonalistyczne, aby zaobserwować sposób, w jaki pew-

\footnotetext{
3 Zob. Rouaud, Jean 1996. Pola chwały. Tłumaczenie Ewa Wende. Warszawa: Państwowy Instytut Wydawniczy.

4 Zob. Tardi, Jacques 1993. C'était la guerre des tranchées. Bruxelles: Casterman.

5 Zob. Schoentjes, Pierre 2001. Poétique de l'ironie. Paris: Seuil; idem 2007. Silhouettes de l'ironie. Genève: Droz.
} 
ne obrazy, pewne sposoby pisania powracały niezależnie od pozycji ideologicznych, często ze sobą przeciwstawnych. Chodziło mi więc o przeprowadzenie pracy nad tekstami pomijanymi przez literaturoznawców z powodu niskiej oceny ich znaczenia dla historii literatury. Podręczniki traktowały je często jako świadectwa i służyły one jako materiał do edukacji obywatelskiej. Z wyjątkiem poezji Apollinaire'a, we Francji nie nastąpiło odnowienie form $\mathrm{w}$ literaturze pod wpływem wojny, w przeciwieństwie do tego, co się wydarzyło w Anglii w twórczości War poets. Przeczytałem wiele powieści i opowiadań, które powracały do tematu wojny wietnamskiej, po publikacji, w roku 1977, Depesz Michaela Herra ${ }^{6}$. Były to książki takich autorów, jak Ron Kovic, Philip Caputo, Tim O’Brien, Robert Mason. Gdy poszerzyłem obszar moich badań o inne wojny, także przy okazji prowadzenia doktoratów (wśród których jest jeden przygotowany w ostatnim czasie), zdałem sobie sprawę, że dokonuje się pewien rodzaj wyspecjalizowania korpusów. Kiedy, około roku 1980, jakiś pisarz chciał wyrazić postawę pacyfistyczną, wybierał jako tło I wojnę i podkreślał motyw cierpienia cielesnego. Wojna wietnamska łączyła się z krytyką imperializmu i dewiacyjnych zachowań żołnierzy. Wojna iracka pozwalała na podjęcie problemu trwałej traumy u weteranów. Wojny w Afryce dawały okazję do obrazowania przemocy traktowanej jako „pierwotna” itd. Jeśli we Francji i szczególnie w Anglii powstało od roku 1980 tyle powieści o I wojnie światowej (czego nie obserwujemy w Niemczech, gdzie pamięta się o tej wojnie jako o klęsce), to dzieje się tak, gdyż dotyczy to wydarzenia, co do którego można było najłatwiej dojść do konsensusu. Ogół społeczeństwa już właściwie zapomniał, o jakie wyzwania chodziło: kto pamięta o dyskusjach, w których ścierali się ze sobą, także w środowisku akademickim, zwolennicy „Kultur” i „Civilisation”? Gdy trzeba było wskazać wrogów, automatycznie myślano o wielkiej finansjerze i o przemysłowcach, tym bardziej że te grupy pozostawały czymś abstrakcyjnym. Oczywistym powodem tego, że przed wyjątkiem, jaki stanowi książka Des hommes Laurenta Mauvigniera ${ }^{7}$, mało powieści o wojnie algierskiej poruszyło szeroką publiczność, jest to, że w tym wypadku niemożliwym jest pominięcie problemu osobistej odpowiedzialności, jaką ponoszą jeszcze dzisiaj liczni żyjący ludzie, czy to znani, czy anonimowi. Wydaje mi się więc, że sukces tematu Wielkiej Wojny daje się wytłumaczyć, przynajmniej po części, jego mocą jednoczenia, podczas gdy inne wojny są nadal źródłem podziałów. „Tradycyjne” bohaterstwo może jeszcze pojawiać się w kontekście II wojny światowej, przedstawianej jako walka $\mathrm{z}$ faszyzmem postrzeganym $\mathrm{w}$ kategoriach absolutnego barbarzyństwa. Ale warunkiem jest tu rozsądny wybór bohatera. Bo pamiętamy aktora Jamela Debouzze'a, w filmie Dni chwały odbezpieczającego granat zębami, jakby był Johnem Waynem. Ale II wojna wciąż dzieli społeczeństwo francuskie, które choć mówi bardziej otwarcie o kolaboracji, niż to miało miejsce wcześniej, nadal nie nabrało dystansu wobec mitu stworzonego wokół ruchu oporu. Nie istnieje więc dzisiaj jakieś jedno wyobrażenie wojny, ale różne wyobrażenia, które wpływają na siebie wzajemnie. Te wyobrażenia mogły pomóc w przemyśleniu konfliktów z końca XX wieku i wciąż wpływają na refleksję nad tymi problemami, nawet jeśli zagrożenie terrorystyczne w ostatnich latach skłania pisarzy do podejmowania tematu przemocy w kontekście zupełnie innym. Jeśli literatura współczesna będzie w stanie utemperować dyskurs prowojenny skierowany przeciw islamowi, odegra

\footnotetext{
6 Zob. Herr, Michael 2016. Depesze. Tłumaczenie Krzysztof Majer. Kraków: Karakter.

7 Zob. Mauvignier, Laurent 2009. Des hommes. Paris: Minuit.
} 
ona rolę, do której nie była zdolna po roku 1870, kiedy to powieści odwetowe podsycały nacjonalizm.

Jakie czynniki, według Pana Profesora, polityczne i kulturowe w dzisiejszym świecie wyjaśniają zjawisko powrotu Historii w literaturze i w szczególności silnej obecności tematu przemocy wojennej?

P. S.: Powrót (ale czy jest to naprawdę powrót?) Historii, a więc w rzeczywistości czegoś, czym od bardzo dawna pasjonuje się Francja, można wyjaśnić częściowo klęską wielkich utopii XX wieku, począwszy od komunizmu. Upadek Muru Berlińskiego oznacza definitywny koniec pewnej epoki, w której - przynajmniej na Zachodzie - można było wierzyć, że idee i ideologie zmienią świat. Inaczej rzecz się ma w rzeczywistości wschodniej, gdzie religia proponuje alternatywną wizję świata, w przypadku ekstremistów jest to wizja brutalna, ale nakierowana na przyszłość. Współczesną nam nieufność wobec literatury zwanej zaangażowaną (chociaż jest ona akceptowana, gdy walczy o zwiększenie sprawiedliwości społecznej) można bez wątpienia wytłumaczyć przemieszczeniem środka ciężkości ze sfery wspólnotowej do przestrzeni indywidualnej. Dziś bardziej myśli się o znalezieniu sobie miejsca w społeczeństwie, niż o reformowaniu go. Obecnie w literaturze wojennej liczy się przedstawianie wszystkich, którzy cierpią. Nie przemilcza już, jak to miało miejsce za czasów Voltaire’a czy Napoleona, tysięcy zabitych, którzy zasługiwali najwyżej na lakoniczną wzmiankę i stanowili tło dla opowiadania o bohaterskich dokonaniach jakiegoś wodza. Ale sukces literackich przedstawień wojennej przemocy tłumaczy się także czymś, o czym się mówi w sposób mniej jawny. Błędem byłoby minimalizowanie faktu, że widok przemocy i okropieństwa pociąga ludzi. Daje się regularnie zauważyć, nawet w literaturze, która według samych autorów ma służyć radykalnemu potępieniu wojny, tendencję do pokazywania z pewnym upodobaniem umęczonych ciał za pomocą strategii pisarskich polegających na uwypuklaniu cierpienia poprzez szczegółowe opisy. W ekstremalnych przypadkach można nawet mówić o swoistej pornografii przemocy. Odwołam się do przykładu, który wykracza poza kontekst ściśle związany z wojną: książki z serii Millenium, cieszące się sukcesem w skali światowej, ujawniają akty przemocy wobec kobiet, a więc skandal bez wątpienia zasługujący na uwagę, problem, który jeszcze w niewystarczający sposób był poruszany w literaturze. Ale kiedy Lisbeth Salander mści się na opiekunie, który ją zgwałcil, jesteśmy świadkiem niesłychanie brutalnej sceny ${ }^{8}$. Kontynuujemy jednak naszą lekturę, usprawiedliwiając $i$ zemstę, $i$ fakt, że nie odkładamy książki, bo mówimy sobie, że jest to kara w pełni zasłużona. Ale kto może powiedzieć, jaka jest doza przyjemności, którą odczuwamy przy lekturze takich stron? Bylibyśmy równie gotowi do odbioru sceny, w której Stieg Larsson ukazywałby gwałt na Lisbeth z takim samym bogactwem szczegółów? Powróćmy do literatury wojennej. Czy obrazowanie skrajnej przemocy pod pretekstem jej potępienia, nie jest do pewnego stopnia grą czymś w rodzaju sensacjonizmu? Nie polega to na tworzeniu pewnego kontekstu, który usprawiedliwia patrzenie? I jaka jest wtedy część odpowiedzialności tego, który patrzy, nawet jeśli chodzi o fikcję? Literatura wojenna musi niechybnie nas skłonić do zastanowienia się nad momentem, w którym wybory estetyczne wpływają

8 Zob. Larsson, Stieg 2009. Dziewczyna, która igrała z ogniem (Millenium t. 2). Tłumaczenie Paulina Rosińska. Warszawa: Wydawnictwo Czarna Owca. 
na kwestie etyczne. Przypomina nam o tym np. przypadek polemicznych recepcji powieści Easkawe Jonathana Littella9.

W swojej książcej Fictions de la Grande Guerre. Variations littéraires sur 14-18 ${ }^{10}$ kładzie Pan Profesor nacisk na funkcję obrazu w narracyjnych sposobach przedstawiania wojny. Analizuje Pan figury, które stały się ikonami w systemie wyobrażeń Wielkiej Wojny: koszmarna rzeczywistość okopów, bohater, trup, zabijanie, oddziały kolonialne, kobiety, rozstrzelani przez pluton egzekucyjny, gazy bojowe. Co motywowało przyjęcie takiej perspektywy badawczej?

P. S.: Chciałem skoncentrować się na tekstach fikcjonalnych, nie traktować ich jako świadectw, jak chętnie czynią to historycy, ale skupić moją uwagę na formie pisarstwa. Zestawiając ze sobą powieści określane jako „nacjonalistyczne” i „pacyfistyczne”, mogłem zaobserwować, że wybory strategii pisarskich bardziej je do siebie zbliżały, niż można było sądzić, mimo że na gruncie ideologicznym były one sobie bardzo odległe. Należało więc na nowo przemyśleć pewne uogólnienia. Są one nie do uniknięcie, kiedy chce się uwzględnić dużą liczbę utworów, niemniej bardziej zaciemniały one te teksty, niż je wyjaśniały. Jeden przykład: literatura o I wojnie uchodzi w podręcznikach za realistyczną, nawet naturalistyczną. Ale o jaki realizm chodzi? Teksty są o wiele bogatsze i różnorodne, niż to się zdaje. Na przykład styl artystyczny mógł służyć do opisu ataku gazami bojowymi, czyli sceny stanowiącej obowiązkowy element w powieściach wojennych... Ale jesteśmy bardzo daleko od „wiernych” opisów tego, czym w rzeczywistości były tego rodzaju ataki, które na długo naznaczyły wyobraźnię. Inny przykład. Kiedy „nacjonalista” przedstawia okropieństwo ran odniesionych przez francuskiego żołnierza, nie chodzi mu o to, by potępić wojnę, ale by uwypuklić „teutońskie barbarzyństwo”.

A co można powiedzieć na temat badań aspektów aksjologicznych ? Dobrze znane są te słowa Jeana Nortona Cru, który tak wyjaśnial cel swoich Témoins $(\text { Świadkowie })^{11}$ : „Co do odwagi, patriotyzmu, ofiary, śmierci, zostaliśmy oszukani i gdy tylko po raz pierwszy znaleźliśmy się pod obstrzałem, natychmiast stało się dla nas jasne kłamstwo anegdoty, historii, literatury, sztuki, opowieści weteranów i oficjalnych dyskursów. To, co widzieliśmy, to, co przeżywaliśmy, nie miało nic wspólnego z tym, czego się spodziewaliśmy, na podstawie tego wszystkiego, co czytaliśmy i co na nam powiedziano. Nie, wojna nie jest rzeczą ludzką: to była oczywistość, której moc nas zmiażdżyła" ${ }^{\prime 2}$. W jakiej mierze teksty, które Pan Profesor określił terminem „fikcji Wielkiej Wojny”, odpowiadają demaskatorskim wyzwaniom, jakie pisaniu o wojnie stawial Norton Cru? On sam, jak wiadomo, był bardzo nieufny wobec powieści wojennej, nazywając ją „fałszywym gatunkiem”"13.

\footnotetext{
9 Zob. Littell, Jonathan 2008. Łaskawe. Tłumaczenie Magdalena Kamińska-Maurugeon. Kraków:Wydawnictwo Literackie.

10 Zob. Schoentjes, Pierre 2009. Fictions de la Grande Guerre. Variations littéraires sur 14-18. Paris: Garnier.

11 Praca, opublikowana w roku 1929, zawierająca analizę ponad 300 tekstów (artykułów prasowych, wspomnień, refleksji, listów i powieści) świadectw kombatantów I wojny.

12 Norton Cru, Jean 2015 (reprint z 1929). Témoins. Essai d'analyse et de critique des souvenirs de combattants édités en français de 1915 à 1928. Paris: Eurédit. 13-14.

13 Norton Cru, Jean 1930. Du témoignage. Paris: Nouvelle Revue Française. 83.
} 
P. S.: Lektura Jeana Nortona Cru i kwerenda w archiwach w Aix-en-Provence, gdzie zachowana jest nie tylko jego biblioteka i część jego korespondencji, ale także jego mapy sztabowe, były dla mnie bardzo ważnym doświadczeniem. Tak się składa, że w czasie studiów miałem zajęcia $\mathrm{z}$ języka starofrancuskiego z profesorem, wymagającym filologiem wykształconym w tradycji literaturoznawstwa pozytywistycznego, który w sposób dość paradoksalny przygotował mnie do kontaktu z perspektywą Nortona Cru. Oprócz kwestii metodologicznych, ten profesor przypominał też Jeana Nortona Cru z powodu bezpośredniości swojego trochę szorstkiego charakteru. Widzę ich ciągle obu jako swoiste wzajemne odbicie i myślę, że to mi pomogło lepiej zrozumieć Świadków. Profesor, wrogo usposobiony wobec tego, co niesłusznie uważał za „impresjonizm” nowej metodologii krytyki tekstów bardziej skupionych na ich formie niż ich osadzeniu w kontekście historycznym i intencjach autorskich, starał się nam zaszczepić postawę pokory dla studiowanych dzieł. Odmawiał on używania, jak to było w zwyczaju w tamtym czasie, terminu "teksty” i bronił konieczności głębokiej znajomości kontekstu historycznego. Zadał nam lekturę bardzo starej pracy: Chateaubriand en Amérique : vérité et fiction (Chateaubriand w Ameryce. Prawda i fikcja) Josepha Bédiera. To ważna analiza, która około roku 1900 po raz pierwszy kładła nacisk na to wszystko, czego Chateaubriand „nie mógł zobaczyć na własne oczy”, i wyszczególniała rozliczne zapożyczenia autora $\mathrm{z}$ dzieł innych podróżników ${ }^{14}$. Ta lektura bardzo mnie naznaczyła, podkopując trochę naiwne zaufanie, które jeszcze mogłem mieć do słów pisarzy. Mimo że nie znalazłem żadnego nawiązania do Bédiera w tym, co czytałem u Nortona Cru i w tekstach na temat tego autora, jestem przekonany, że w swojej edukacji literackiej musiał się zapoznać z Chateaubriandem w Ameryce. Podtytuł Prawda i fikcja, dziś banalny, określa już program. Ale niezależnie od bezpośredniego wpływu: sedno metody Nortona Cru odpowiada bezpośrednio modelowi zastosowanemu przez Bédiera. Podpisuję się pod ambicją, która motywowała pracę Nortona Cru: niczemu nie służy skłanianie do nienawidzenia wojny, jeśli tworzy się jej fałszywy obraz. Pacyfizm nie ma pożytku z dzieł, które ukazują wojnę taką, jaką ona nie jest. Nawet gdyby zastosowane wybory narracyjne były udane z punktu widzenia estetycznego i skuteczne ideologicznie. Zresztą kwestia skuteczności jest czymś bardzo niepewnym. Zwracano już od dawna uwagę, że od starożytności istnieją realistyczne opisy walk i że jednak nie powstrzymały one kolejnych wojen.

A czy prace krytyczne na temat Wielkiej Wojny zgłębiły, według Pana Profesora, wystarczająco problem obecności dyskursów kłamliwych i/lub demaskatorskich w tekstach fikcjonalnych?

P. S.: Dużo w tej dziedzinie zostało zrobione przez historyków (jeśli chodzi np. o zagadnienia takie jak nacjonalizm, walka, dzieci... ), ale literatura traktowana pod kątem formy nie jest ich podstawowym obszarem badań. Interesującym byłoby studium systemów wartości wyrażanych za pośrednictwem tych licznych powieści, które od roku 1980 powracają do tematu Wielkiej Wojny. W zdecydowanej większości wpisują się one w tradycję, której ilustracją jest powieść, z roku 1931, Wielka trzoda (tytuł oryginalny Le grand troupeau) Jeana Giono ${ }^{15}$. Chodzi o przedstawianie okropieństw wojny w celu uwolnienia

14 Zob. Bédier, Joseph 1899. „Chateaubriand en Amérique : vérité et fiction”. Revue d'Histoire Littéraire de la France 4: 501-532.

15 Zob. Giono, Jean 1936. Wielka trzoda. Tłumaczenie Henryk Leśniewski. Warszawa-Poznań-Kraków-Lwów: Renaissance. 
ludzkości od tej rany. Przykłada się tu wielkie znaczenie, zasadnicze w powieści Giono, do obrazu przyrody wartościowanej jako kontrast dla wojny. Fascynujące jest widzieć dzisiaj prace poświęcone Wielkiej Wojnie, których autorzy interesują się sytuacją zwierząt i to poza kontekstem etyki zwierząt. Zwierzęta odgrywają zresztą coraz większą rolę we współczesnej literaturze fikcjonalnej. Umieszczenie ich w centrum nowych opowieści o wojnie było jednym ze sposobów reinterpretacji tego tematu, po tym, jak pisarze zainteresowali się problemem kobiet, które nie były przedstawiane jako podmioty działające w powieściach o wojnie okopowej.

Czy dzisiaj, sto lat po Wielkiej Wojnie, są jakieś tematy, przemilczenia, stereotypy na jej temat, których literatura jeszcze nie poruszyla?

P. S.: Prawdziwych tabu nie widzę, choć dość rzadką jest sytuacja, w której postać będąca jednocześnie narratorem pierwszoosobowym przedstawiałaby siebie w chwili zabijania kogoś własnymi rękami. Dominująca perspektywa, nadal, to ta, w której żołnierz ukazany jest jako ofiara, i przechodzi się zawsze dość szybko nad faktem, że jego główna rola nie polega na umieraniu, ale na zabijaniu. Tak naprawdę obraz żołnierza-ofiary nie został zakwestionowany, nawet jeśli doszło do kontestacji wyższości moralnej (i politycznej), o której to ocaleni myśleli, że mogą ją sobie przypisywać z powodu przebytych doświadczeń. Podstawowa matryca, poprzez którą współczesne fikcje odczytują Wielką Wojnę ciągle oparta jest na wizji utrwalonej przez kombatantów, z tą jednak znaczącą różnicą, że teraz wyraża się otwarcie sympatię dla zbuntowanych żołnierzy, dezerterów i rozstrzelanych dla przykładu.

Jakie widzi Pan Profesor możliwości i/lub ograniczenia podejść komparatystycznych do tematu Wielkiej Wojny w literaturach współczesnych?

P. S.: Wolę mówić o „problematyce” niż o „temacie”, ze względu na moją nieufność do tematologii jako metody literaturoznawczej. Uprawiali ją wyjątkowi krytycy. Ale ja jestem nieufny z powodu tendencji, która może skłaniać do podciągania pod termin „temat” badań pozbawionych wszelkiej refleksji nad wyborem narzędzi bądź teorii. Myślałem, że zainteresowanie I wojną będzie się zmniejszać już w okresie poprzedzającym komemoracje związane ze stuleciem i że wygaśnie po roku 2018. Wygląda jednak, że tak się nie dzieje. Liczne powieści, jak np. wydana niedawno L’odeur de la forêt (Zapach lasu) Hélène Gestern $(2016)^{16}$, znajdują ciągle nowe sposoby opowiadania o tej epoce. Myślałem też, że badacze zwrócą się ku innym obszarom, ale tu też zainteresowanie Wielką Wojną się utrzymuje. Wynika to z pewnością z faktu, iż nowe pokolenie młodych badaczy wyspecjalizowało się w tej problematyce i zainteresowanie nią nie zakończy się wraz z dniem 11 listopada 2018. Ale mam też przeczucie, że z upływem lat umacniać się będzie w literaturze fikcjonalnej zainteresowanie II wojną, wykraczając poza kwestię Szoah, która od dawna przykuwa uwagę twórców i czytelników. Jeśli chodzi o kierunki badań, najbardziej interesujące wydają mi się te, które z rozmysłem odchodzą od narodowych perspektyw i tradycji literackich. W czasach kiedy czytelnicy nie ograniczają swoich wyborów do jedynej przestrzeni narodowej, kiedy rozwija się znajomość języków obcych, a dzięki tłumaczeniom ma się dostęp do coraz

\footnotetext{
16 Powieść o odkrywaniu losów uczestników I wojny, odznaczająca się różnorodnością form narracyjnych (analizy fotografii, dziennika, korespondencji). Gestern, Hélène 2016. L'odeur de la forêt. Paris: Arléa.
} 
większej liczby utworów, szkoda byłoby zamykać podejścia akademickie w granicach jednego dziedzictwa. Trauma-studies, dominujące w anglosaskim środowisku akademickim, z pewnością unowocześnily perspektywy naukowe. Ale gdyby perspektywa trauma-studies miała się stać jedynym sposobem badania literatury, duże obszary powieściopisarstwa pozostałby niewyeksplorowane. Wydaje mi się pożądanym pomnażanie podejść naukowych, zarówno tutaj, jak i w innych obszarach. Gdyby dominacja tematyki Wielkiej Wojny w świecie literackim miała ustępować, działoby się to prawdopodobnie na rzecz zwiększenia zainteresowania aktualnością innej formy przemocy, jaką jest terroryzm ekstremistów muzułmańskich. Można zauważyć, że coraz większa liczba pisarzy umieszcza tę kwestię w swoich utworach, a są i tacy, którzy pod tym kątem nawet zmodyfikowali teksty już w trakcie ich pisania. Tak jak to uczynił Proust, czując się zobligowany do zreorganizowania $W$ poszukiwaniu straconego czasu, aby w dziele znalazło się miejsce dla Wielkiej Wojny. Jest oczywistym, że wyobrażenia związane $\mathrm{z}$ kwestią tej nowej formy skrajnej przemocy poddają się przemyśleniom w zupełnie innym kontekście, w którym refleksja nad zagadnieniami religijnymi, prawie nieobecna w literaturze francuskiej przywołującej I wojnę, znowu będzie się narzucać. Zaznaczyła się już ona zresztą w powieściach o wojnie w byłej Jugosławii. 